\title{
Ecological interactions between wild and hatchery salmonids: an introduction to the special issue
}

\author{
Peter S. Rand • Barry A. Berejikian • \\ Todd N. Pearsons • David L. G. Noakes
}

Received: 18 January 2012 / Accepted: 12 February 2012

(C) Springer Science+Business Media B.V. 2012

The optimism of early salmon hatchery practitioners to increase abundance (Lichatowich 1999) has been tempered in recent decades by theoretical and empirical studies indicating unintended negative effects hatcheries can have on wild Pacific salmon and steelhead (Naish et al. 2008; Pearsons and Temple 2010). Unintended effects of hatcheries are much more difficult and costly to assess than evaluating the benefits of hatchery production to provide harvest opportunities. Holistically evaluating the relative costs and benefits of past and current hatchery practices requires an understanding and estimation of the unintended effects (Pearsons 2010). In recent years, national and local governments, indigenous

P. S. Rand $(\bowtie)$

State of the Salmon, Wild Salmon Center,

Portland, OR, USA

e-mail: prand@wildsalmoncenter.org

\section{B. A. Berejikian}

NOAA Northwest Fisheries Science Center,

Manchester, WA, USA

T. N. Pearsons

Grant County Public Utility District,

Ephrata, WA, USA

D. L. G. Noakes

Department of Fisheries and Wildlife and Oregon Hatchery

Research Center, Oregon State University,

Corvallis, OR 97331-3803, USA (e.g. First Nations or tribal) resource agencies, private industry and NGO conservation groups have begun efforts to reform public salmon and steelhead hatchery systems in North America, which include critically evaluating societal and biological risks and benefits.

A significant number of national and international policy concerns and actions are directly relevant to this issue. In the US Pacific Northwest, for example, the National Oceanic and Atmospheric Administration (NOAA) is currently evaluating the environmental impact of salmon and steelhead hatcheries through federal mandates such as the Endangered Species Act and the Mitchell Act. The US State of Alaska is faced with ongoing challenges of adhering to the State's fisheries policies regarding sustainability, genetics and escapement goals in the face of a growing private salmon hatchery industry in the State. In Canada, the Department of Fisheries and Oceans (DFO) is in the process of implementing an ambitious new Wild Salmon Policy that must address impacts hatcheries have on wild salmon. There is fresh thinking and emerging new initiatives in both Japan and Russia to identify and separately manage wild salmon in these nations.

The growing demand for sustainable seafood has put the global spotlight on salmon, which is near the top of the list of most desired seafood, buoyed by reports of health benefits of eating salmon. Third party sustainability certifications of wild capture fisheries is required in many global markets, and Pacific salmon 
fisheries are coming under increased international scrutiny with respect to how salmon hatcheries are managed and the degree to which hatchery salmon interact with and affect wild salmon, both genetically and ecologically (Peterman 2002; Chaffee and Bosworth 2007). Salmon populations (comprised of both wild or hatchery populations, or a mixture of the two) also continue to play a critical role in supporting subsistence, ceremonial and recreational fisheries across the North Pacific region.

The effects of hatchery-produced salmon on aquatic ecosystems have been vigorously debated in academic and natural resource forums and in the scientific literature. The attention to hatchery effects has resulted in coordinated efforts to reform the public hatchery system in the United States and led to very specific guidelines to mitigate genetic impacts (Mobrand et al. 2005; Paquet et al. 2011). Although genetic interactions have received most of the attention in the scientific literature (Waples 1991; Araki et al. 2008; Fraser 2008; Christie et al. 2011), negative associations between the numbers of hatchery fish released and wild salmon survival rates have been hypothesized to be the result of ecological interactions (e.g., Nickelson 2003). Indeed, a number of recent reviews highlight the potential importance and gaps in our understanding of the ecological effects of hatchery salmon on wild salmon populations and their freshwater and marine habitats (Naish et al. 2008; Pearsons 2008). In 2009, a small group of scientists and policy makers recognized the need and value of convening a diverse group of experts and stakeholders to describe what is known about the scale and magnitude of ecological interactions between wild and hatchery salmonids, and to describe a logical path forward to address unintended effects hatchery salmonids can have on wild salmonids throughout their native range in the North Pacific.

The papers contained in this volume are a product of convening experts and stakeholders at a conference entitled "Ecological Interactions Between Wild and Hatchery Salmon". The meeting was organized by State of the Salmon and held on 4-7 May 2010 in Portland, Oregon, USA. Our conference aimed to present the most current information about ecological interactions, identify critical scientific uncertainties, identify available tools for managing ecological risks, and to develop a path forward for improving the understanding and management of ecological interactions between wild and hatchery salmonids in the North Pacific region. The conference was the first pan-Pacific event designed to explore the scale and magnitude of the ecological effects of salmon and steelhead hatcheries. Over 300 people attended the meeting and participants in the conference hailed from the United States, Canada, Russia, and Japan. The conference agenda included 47 talks and was organized into seven separate sessions. This special journal issue represents 23 original scientific investigations and reviews on ecological interactions. We also encourage the reader to visit the conference website (http://www.stateofthesalmon.org/conference2010/) for additional information.

The agenda and expected outcomes from the conference were shaped by a steering committee composed of agency and academic experts from the United States, Canada, Russia and Japan. The steering committee members were as follows (listed in alphabetical order):

Brian Allee, NOAA

Barry Berejikian, NOAA

Stephen Brandt, Oregon Sea Grant

Dan Bottom, NOAA

Craig Busack, Washington Department of Fish and Wildlife

Ken Currens, Northwest Indian Fisheries Commission

Robert Devlin, Department of Fisheries and Oceans, Canada

Ian Fleming, Memorial University

Susan Hanna, Oregon State University

Masahide Kaeriyama, Hokkaido University

David Noakes, Oregon State University

Ken Ostrand, U.S. Fish and Wildlife Service

Todd Pearsons, Grant County Public Utility District

Pete Rand, State of the Salmon

Bill Smoker, University of Alaska Fairbanks (retired) Alex Wertheimer, NOAA (retired)

Lev Zhivotovsky, Institute of General Genetics, Russian Academy of Sciences

While we sought to encourage wide ranging participation and perspectives at the conference, the guest editors wish to emphasize that any views or suggestions expressed in this special issue are not intended to represent the views of any particular salmon management entity whose jurisdiction includes the North Pacific. We do hope, however, that views and perspectives expressed are thought provoking and help spur meaningful dialogue toward an important goal of conserving wild salmon. 
The structure of this special issue addresses the ecological interactions between wild and hatchery salmon and steelhead as a life history progression across ontogenetic stages and habitats. In addition, a number of review and perspective papers were presented at the conference. Below we provide an overview on the unique contribution made by each of the authors in this special issue.

We began by examining interactions occurring in the early life history of Pacific salmon and steelhead in freshwater. A review of juvenile salmon competition described how factors including duration of freshwater cohabitation, relative body size, prior residence, and species differences all influence competitive interactions, with fish density in relation to habitat carrying capacity likely exerting the greatest influence (Tatara and Berejikian 2012, this issue). Another review described evidence of predation by stocked hatchery steelhead on juvenile wild salmon (Naman and Cameron 2012, this issue) exemplifying the variability in predation rates that can be associated with timing of emergence and hatchery release practices. This paper provided practical suggestions on how to minimize predation risk through hatchery management changes. Manipulation of growth regimes in steelhead hatchery facilities to induce more natural life history expression and minimize negative effects on wild fish further exemplified efforts to reform hatchery practices to minimize predation and competition risks of released steelhead trout during their freshwater residence (Berejikian et al. 2012, this issue).

A unique modeling tool (PCD Risk 1) has been developed for conducting risk assessment and facilitating risk reduction associated with predation, competition and disease among salmonids in freshwater environments (Pearsons and Busack 2012, this issue). Methods to manage ecological risks of a hatchery program in the US State of Washington were used to reduce adverse impacts to a variety of non-target taxa, which are frequently overlooked (Temple and Pearsons 2012, this issue). And, a broad scale risk assessment approach using the PCD Risk 1 model and expert based opinion is described for the Upper Columbia River, USA/Canada (Pearsons et al. 2012, this issue).

Following the freshwater juvenile stage, smolts originating from natural spawning habitat and hatcheries may differ in their early marine life histories but may still compete during their seaward migration. Wild and hatchery chum salmon in inlet and near shore habitats in Southeast Alaska, USA partitioned diets and habitat resources, which suggests transitory effects of density-dependent competition between wild and hatchery chum salmon during the early marine phase of the life cycle (Sturdevant et al. 2012, this issue). A similar study on Chinook salmon in waters off the coast of the US States of Oregon and Washington showed less differentiation in diet and habitat use among wild and hatchery individuals, with evidence that both populations responded synchronously to ocean conditions (Daly et al. 2012, this issue). A study in coastal British Columbia suggests wild Chinook salmon may be more resilient to future climate change than their hatchery counterparts given observations of higher near shore survival of wild postsmolts (Beamish et al. 2012, this issue). There remains substantial uncertainty regarding the interpretation of spatial, temporal, and dietary overlap between hatchery and wild fish during their early life history in the marine environment, but these studies have provided a starting point for understanding some of the conditions under which overlap can occur, the degree of overlap in different regions, and some initial interpretations of its significance.

Less is known about the offshore marine life history of Pacific salmon. However, two papers in the special issue have "lifted the curtain" on the potential interactions occurring between wild and hatchery salmon in the open ocean. An increase in Asian hatchery chum salmon abundance from 10 million to 80 million fish may have influenced body size, age-at-maturation, productivity and abundance of a distant wild chum salmon population in Norton Sound, Alaska (Ruggerone et al. 2012, this issue). Growth and survival of North Pacific salmon are declining as a result of competitive interactions among salmon at sea, a process that may be exacerbated by hatchery programs for pink and chum salmon and future climate change (Kaeriyama et al. 2012, this issue).

A number of studies addressed interactions occurring at the time of adult return migration and spawning. Recent research was presented on straying of hatchery produced pink, chum and sockeye salmon in Prince William Sound, Alaska. This helps frame some of the challenges in minimizing adverse effects of hatchery populations on wild salmon in this region (Brenner et al. 2012, this issue). The first comprehensive salmon escapement survey of chum salmon in Hokkaido, Japan, provided evidence of natural reproduction in a region that has focused for many decades on hatchery development (Miyakoshi et al. 2012, this issue). The unique history of hatchery development in Sakhalin, Russian Federation and the emerging understanding of 
interactions between wild and hatchery pink and chum salmon provides insight into potential competition between wild and hatchery salmon in this region (Kaev 2012, this issue). New evidence was presented on trait divergence between wild and hatchery populations of chum, Chinook and sockeye populations in southern Kamchatka, Russian Federation and the first documentation in the literature on the contribution of hatchery chum salmon to the natural spawning population of chum salmon in this region (Zaporozhets and Zaporozhets 2012, this issue).

Three additional papers address reproductive interactions and demonstrate the power of genetic tools in understanding the nature of ecological interactions between wild and hatchery salmon. Shifting demographics of hatchery Chinook salmon populations to earlier male maturity may influence overall DNA pedigree-based estimates of reproductive success in natural populations supplemented with hatchery-reared Chinook salmon (Schroder et al. 2012, this issue). A study of genetic markers reveals how a rare lake-type chum population is being swamped by a rapidly expanding hatchery chum salmon population in a small island in the Kurile archipeligo, Russian Federation (Zhivotovsky et al. 2012, this issue). Genetic differences among cultured and wild populations of masu salmon in Hokkaido, Japan were highlighted in another study, and the authors urged fisheries managers to consider the risk of fitness loss in wild masu populations that might interbreed with hatchery fish (Yu et al. 2012, this issue).

A number of broad reviews were presented on different dimensions of the conference theme. A succinct summary of enhancement of Alaska salmon fisheries noted many of the positive benefits to the fishery and the state (Heard 2012, this issue). A summary of five case studies provides a rich description of the history, ecological dimensions, and the interplay between emerging scientific information and the creation of public policy in the US Pacific Northwest context, concluding with some practical suggestions on how to effectively contain risks in the future (Kostow 2012, this issue). A cogent argument for developing and implementing a new wild salmon policy in Japan was introduced (Nagata et al. 2012, this issue), emphasizing reforms needed to conserve remaining natural reproductive components of Japanese salmon and to restore degraded salmon habitat. Theory and empirical studies highlight the risks of hatchery fish eroding the potential for adaptation in wild salmon, and underscores the importance of protecting wild populations to achieve sustained harvests of Alaskan salmon (Grant 2012, this issue). Finally, a regional synthesis paper summarizing the state of understanding of ecological interactions across the diverse North Pacific region highlighted efforts underway or planned to increase our understanding and identify needed actions to minimize negative effects in the context of fisheries management (Rand et al. 2012, this issue).

We were encouraged by the positive testimonials that we received during and following the conference. We hope that this special issue will further inspire collaboration among scientists, managers, conservationists, indigenous peoples, fishers, business people, and politicians and serve as a long-term record of the conference. Furthermore, our hope is that through collaboration we can increase our understanding and advance the management of ecological interactions so that beneficial interactions can be facilitated and detrimental interactions can be minimized.

Acknowledgements We would like to thank the many sponsors of our 2010 conference, particularly our main sponsor, the Gordon and Betty Moore Foundation. We received additional support from the following entities: US Fish \& Wildlife Service, National Oceanic and Atmospheric Administration, Sea Grant College Programs of Oregon, Washington and California, Oregon and British Columbia-Washington Chapters of the American Fisheries Society, National Marine Technologies, Skeena Wild Conservation Trust, Pacific Salmon Foundation, Long Live the Kings, Northwest Power and Conservation Council, Marine Stewardship Council, Deschutes Brewery, Bodhichitta Winery, Pacific Rim Winery, Bridgeport Brewery, Keen, Indian Country Conservancy, Washington State Recreation and Conservation Office, Smith Root Inc., and Icebreaker. We would like to particularly thank Wild Salmon Center staff for organizing the event, including Sarah O’Neal, Cathy Kellon, Josh McLaughlin and Rich Lincoln. We also wish to thank the many student volunteers that provided much needed assistance during the event. We thank the VIP conference speakers, including Spencer Beebe, Ray Hilborn, Jim Martin, Guido Rahr, Don Sampson, Jack Stanford, and Rob Walton. We would especially like to thank Tom Brokaw for delivering an inspirational and memorable dinner address at the Portland Art Museum to kick off our conference. Finally, we express our gratitude to Roy Stein, for providing a fresh perspective on this issue at the conference, and for ably moderating the final panel and providing a thoughtful synthesis on the final day of our gathering that helped us shape this special issue.

\section{References}

Araki H, Berejikian BA, Ford MJ, Blouin MS (2008) Fitness of hatchery-reared salmonids in the wild. Evolution Appl 1 (2):342-355. doi:10.1111/j.1752-4571.2008.00026.x

Beamish RJ, Sweeting RM, Neville CM, Lange KL, Beacham TD, Preikshot D (2012) Wild chinook salmon survive 
better than hatchery salmon in a period of poor production. Environ Biol Fish. doi:10.1007/s10641-011-9783-5

Berejikian BA, Larsen DA, Swanson P, Moore ME, Tatara CP, Gale WL, Pasley CR, Beckman BR (2012) Development of natural growth regimes for hatchery-reared steelhead to reduce residualism, fitness loss, and negative ecological interactions. Environ Biol Fish. doi:10.1007/s10641-0119788-0

Brenner RE, Moffitt SD, Grant WS (2012) Straying of hatchery salmon in Prince William Sound, Alaska. Environ Biol Fish. doi:10.1007/s10641-012-9975-7

Chaffee C, Bosworth R (2007) Case Study 2: the Alaska salmon. In: Phillips B, Ward T, Chaffee C (eds) Eco-labelling in fisheries: what is it all about? Blackwell Science Ltd, Oxford. doi:10.1002/9780470995471.ch9

Christie MR, Marine ML, French RA, Blouin MS (2011) Genetic adaptation to captivity can occur in a single generation. PNAS 109:238-242

Daly EA, Brodeur RD, Fisher JP, Weitkamp LA, Teel DJ, Beckman BR (2012) Spatial and trophic overlap of marked and unmarked Columbia River Basin spring Chinook salmon during early marine residence with implications for competition between hatchery and naturally produced fish. Environ Biol Fish. doi:10.1007/s10641-011-9857

Fraser DJ (2008) How well can captive breeding programs conserve biodiversity? A review of salmonids. Evolution Appl 1 (4):535-586. doi:10.1111/j.1752-4571.2008.00036.x

Grant WR (2012) Understanding the adaptive consequences of hatchery-wild interactions in Alaska salmon. Environ Biol Fish. doi:10.1007/s10641-011-9929-5

Heard WR (2012) Overview of salmon stock enhancement in southeast Alaska and compatibility with maintenance of hatchery and wild stocks. Environ Biol Fish. doi:10.1007/ s10641-011-9855-6

Kaeriyama M, Seo H, Kudo H, Nagata M (2012) Perspectives on wild and hatchery salmon interactions at sea, potential climate effects on Japanese chum salmon, and the need for sustainable salmon fishery management reform in Japan. Environ Biol Fish. doi:10.1007/s10641-011-9930-z

Kaev AM (2012) Wild and hatchery reproduction of pink and chum salmon and their catches in the Sakhalin-Kuril region, Russia. Environ Biol Fish. doi:10.1007/s10641-011-9900-5

Kostow K (2012) Strategies for reducing the ecological risks of hatchery programs: case studies from the Pacific Northwest. Environ Biol Fish. doi:10.1007/s10641-011-9868-1

Lichatowich JA (1999) Salmon without rivers: a history of the Pacific salmon. Island Press, Washington, DC

Miyakoshi Y, Urabe H, Saneyoshi H, Aoyama T, Sakamoto H, Ando D, Kasugai K, Mishima Y, Takada M, Nagata M (2012) The occurrence and run timing of naturally spawning chum salmon in northern Japan. Env Biol Fish. doi:10.1007/s10641-011-9872-5

Mobrand LE et al (2005) Hatchery reform in Washington State: principles and emerging issues. Fisheries 30(6):11-23

Nagata M, Miyakoshi Y, Urabe H, Fujiwara M, Sasaki Y, Kasugai K, Torao M, Ando D, Kaeriyama M (2012) An overview of salmon enhancement and the need to manage and monitor natural spawning in Hokkaido, Japan. Env Biol Fish. doi:10.1007/s10641-011-9882-3

Naish KA et al (2008) An evaluation of the effects of conservation and fishery enhancement hatcheries on wild populations of salmon Advances in Marine Biology. Adv Mar Biol 53:61194

Naman AW, Cameron SS (2012) Predation by hatchery yearling salmonids on wild subyearling salmonids in the freshwater environment: A review of studies, two case histories, and implications for management. Environ Biol Fish. doi:10.1007/s10641-011-9819-x

Nickelson T (2003) The influence of hatchery coho salmon (Oncorhynchus kisutch) on the productivity of wild coho salmon populations in Oregon coastal basins. Can J Fish Aquat Sci 60(9):1050-1056. doi:10.1139/f03-091

Paquet PJ, Flagg T, Appleby A, Barr J, Blankenship L, Campton D, Delarm M, Evelyn T, Fast D, Gislason J, Kline P, Maynard D, Mobrand L, Nandor G, Seidel P, Smith S (2011) Hatcheries, conservation, and sustainable fisheriesachieving multiple goals: results of the hatchery scientific review group's Columbia River basin review. Fisheries 36 (11):547-561

Pearsons TN (2008) Misconception, reality, and uncertainty about ecological interactions and risks between hatchery and wild salmonids. Fisheries 33(6):278-290. doi:10.1577/ 1548-8446-33.6.278

Pearsons TN (2010) Operating hatcheries within an ecosystem context using the adaptive stocking concept. Fisheries 35 (1):23-31

Pearsons TN, Busack C (2012) PCD Risk 1: a tool for assessing and reducing ecological risks of hatchery operations in freshwater. Environ Biol Fish. doi:10.1007/s10641-0119926-8

Pearsons TN, Murdoch AR, Mackey G, Murdoch KG, Hillman TW, Cooper MR, Miller JL (2012) Ecological risk assessment of multiple hatchery programs in the upper Columbia watershed using Delphi and modeling approaches. Environ Biol Fish. doi:10.1007/932 s10641-011-9884-1

Pearsons TN, Temple GM (2010) Changes to rainbow trout abundance and salmonid biomass in a Washington watershed as related to hatchery salmon supplementation. Trans Am Fish Soc 139(2):502-520. doi:10.1577/ t08-094.1

Peterman RM (2002) Ecocertification: an incentive for dealing effectively with uncertainty, risk and burden of proof in fisheries. Bull Mar Sci 70(2):669-681

Rand PS, Berejikian B, Bidlack A, Bottom D, Gardner J, Kaeriyama M, Lincoln R, Nagata M, Pearsons TN, Schmidt M, Smoker W, Weitkamp L, Zhivotovsky LA (2012) Ecological interactions between wild and hatchery salmon and key recommendations for research and management actions in selected regions of the North Pacific. Environ Biol Fish. doi:10.1007/ s10641-012-9988-2

Ruggerone GT, Agler BA, JL Nielsen (2012) Evidence for competition at sea between Norton Sound chum salmon and Asian hatchery chum salmon. Environ Biol Fish. doi:10.1007/s10641-011-9856-5

Schroder SL, Knudsen CM, Pearsons TN, Kassler TW, Beall EP, Young SF, Fast DE (2012) Breeding success of four male life history types of spring Chinook Salmon spawning in an artificial stream. Environ Biol Fish. doi:10.1007/ s10641-011-9789-z

Sturdevant MV, Fergusson E, Hillgruber N, Reese C, Orsi J, Focht R, Wertheimer A, Smoker B (2012) Lack of trophic competition among wild and hatchery juvenile chum salmon during 
early marine residence in Taku Inlet, Southeast Alaska. Environ Biol Fish. doi:10.1007/s10641-011-9899-7

Tatara CP, Berejikian BA (2012) Mechanisms influencing competition between hatchery and wild juvenile anadromous Pacific salmonids in fresh water and their relative competitive abilities. Environ Biol Fish. doi:10.1007/s10641-011-9906-Z

Temple GM, Pearsons TN (2012) Risk management of nontarget fish taxa in the Yakima River Watershed associated with hatchery salmon supplementation. Environ Biol Fish. doi:10.1007/s10641-011-9811-5

Waples RS (1991) Genetic interactions between hatchery and wild salmonids: lessons from the Pacific Northwest. Can J Fish Aquat Sci 48:124-133

Yu JN, Azuma N, Abe S (2012) Genetic differentiation between collections of hatchery and wild masu salmon
(Oncorhynchus masou) inferred from mitochondrial and microsatellite DNA analyses. Environ Biol Fish. doi:10.1007/s10641-011-9869-0

Zaporozhets OM, Zaporozhets GV (2012) Some consequences of Pacific salmon hatchery production in Kamchatka: changes in age structure and contributions to natural spawning populations. Environ Biol Fish. doi:10.1007/ s10641-011-9932-x

Zhivotovsky LA, Fedorova LK, Rubtsova GA, Shitova MV, Rakitskaya TA, Prokhorovskaya VD, Smirnov BP, Kaev AM, Chupakhin VM, Samarsky VG, Pogodin VP, Borzov SI, Afanasiev KI (2012) Rapid expansion of an enhanced stock of chum salmon and its impacts on wild population components. Env Biol Fish. doi:10.1007/s10641-0119873-4 